\title{
Analisis Tingkat Keberhasilan Program Latihan Pasca Cedera Olahraga pada Atlet Olahraga Permainan Bola Besar
}

\author{
Mohammad Thoyfur*, Rias Gesang Kinanti, Ahmad Abdullah \\ Universitas Negeri Malang, Jl. Semarang No. 5 Malang, Jawa Timur, Indonesia \\ *Penulis korespondensi, Surel: thoyfurmohammad03@gmail.com
}

Paper received: 23-7-2021; revised: 13-8-2021; accepted: 20-8-2021

\begin{abstract}
Sports injury is any form of activity that exceeds the body's ability threshold due to sports. A sports injury is a system or body frame that feels pain due to sports activities, so that it can cause defects, injuries, and damage to muscles, joints, bones and other parts of the body. Sports injuries will greatly interfere with the performance of athletes, and can even prevent them from achieving. The postinjury program will be a concern for all sports players, including athletes. The purpose of this research is to determine the level of success of post-sports injury training programs in big soccer athletes in Malang City. This research method uses descriptive quantitative by using a survey approach. The number of respondents in this study were 21 male athletes of soccer, basketball, volleyball and futsal, KONI Malang City using Proportionate Stratified Random Sampling. The results of the study using the IBM SPSS 26.0 analysis technique obtained a mean value of 95.5 and a standard deviation of 12.278. This means that the success rate of the post-sports injury program of respondents in the balanced category with the number of balanced categories amounting to 10 or 47.6 percent while in the very unsuccessful category it is 1 or 4.8 percent, 6 or 28.6 percent unsuccessful, while successful and very successful amounted to 2 or 9.5 percent of the total respondents. The results of the study can be concluded that the level of success of post-sports injury training programs in big soccer athletes at KONI Malang is in a balanced category. It is necessary to increase the post-sports injury training program and how to treat it, so that proper handling when injured and athletes can return get well and fit in no time.
\end{abstract}

Keywords: injury; rehabilitation; success

\begin{abstract}
Abstrak
Cedera olahraga merupakan segala bentuk kegiatan yang melampaui batas ambang kemampuan tubuh akibat olahraga. Cedera olahraga merupakan suatu sistem atau rangka tubuh yang merasakan sakit dikarenakan oleh aktivitas olahraga, sehingga dapat menimbulkan cacat, luka, dan rusak pada otot, sendi, tulang dan bagian lain dari tubuh. Cedera olahraga sangat akan mengganggu performa dari atlet, bahkan bisa menghambat mereka untuk mencapai prestasi. Program pasca cedera akan menjadi perhatian bagi semua pelaku olahraga tak terkecuali atlet. Tujuan dilakukan penelitian ini yaitu untuk mengetahui tingkat keberhasilan program latihan pasca cedera olahraga pada Atlet Bola Besar Kota Malang. Metode penelitian ini menggunakan kuantitatif deskriptif dengan menggunakan pendekatan survei. Jumlah responden dalam penelitian ini yaitu 21 Atlet putra Sepakbola, Bolabasket, Bolavoli dan Futsal KONI Kota Malang dengan menggunakan Proportionate Stratified Random Sampling. Hasil penelitian menggunakan teknik analisis IBM SPSS 26.0 didapatkan nilai mean 95,5 dan standar deviasi 12,278. Artinya tingkat keberhasilan program pasca cedera olahraga responden dalam kategori berimbang dengan jumlah dari kategori berimbang berjumlah 10 atau 47,6 persen sementara dalam kategori sangat tidak berhasil berjumlah 1 atau 4,8 persen, tidak berhasil berjumlah 6 atau 28,6 persen, sedangkan berhasil dan sangat berhasil berjumlah 2 atau 9,5 persen dari total responden. Hasil penelitian dapat disimpulkan bahwa tingkat keberhasilan program latihan pasca cedera olahraga pada atlet olahraga permainan bola besar di KONI Kota Malang dalam kategori berimbang, Perlu adanya peningkatan program latihan pasca cedera olahraga dan cara merawatnya, agar dapat penanganan yang tepat saat mengalami cedera dan atlet dapat kembali sembuh dan bugar dengan waktu yang singkat.
\end{abstract}

Kata kunci: cedera; rehabilitasi; keberhasilan 


\section{Pendahuluan}

Olahraga merupakan aktivitas yang melibatkan komponen-komponen kesegaran jasmani, dengan begitu olahraga juga dapat dikatakan sebagai penjamin kualitas hidup bagi manusia. Olahraga sendiri sangat diminati oleh berbagai lapisan masyarakat Indonesia mulai dari kalangan dewasa hingga anak-anak.

Olahraga juga dapat dijadikan wadah untuk mengembangkan potensi prestasi bagi umat manusia. Ketika melakukan aktivitas olahraga atlet memerlukan kondisi fisik yang prima. Apabila dalam latihan kondisi atlet tidak memungkinkan dan terus menerus dipaksa menyelesaikan program latihan yang berlebih maka hal tersebut dapat berpengaruh pada kondisi dimana atlet tersebut mengalami kelelahan dan dapat mengakibatkan cedera pada atlet tersebut (Dwiariani, 2012).

Olahraga yang paling sering terjadi cedera adalah olahraga permainan, terutama seperti pada cabang olahraga tertentu seperti Sepakbola, futsal, bolavoli dan bolabasket. Olahraga tersebut merupakan salah satu jenis permainan yang melibatkan berbagai struktur atau jaringan pada tubuh manusia, yaitu sendi, otot, meniscus/discus, tulang guna melakukan gerakan yang kompleks saat melakukan olahraga permainan tersebut. Gerakan tersebut adalah gerakan-gerakan dasar yang harus dikuasai oleh seorang atlet seperti latihan kondisi fisik dan keterampilan teknik permainan sepakbola, futsal, bolavoli maupun bolabasket.

Penyebab cedera olahraga biasanya akibat dari trauma/benturan langsung ataupun latihan yang berulang-ulang dalam waktu lama. Penyebab ini dapat dibedakan menjadi: 1) Faktor dari luar, yaitu: (a) cabang olahraga itu sendiri. (b) Alat olahraga. (c) Kondisi lapangan: licin, tidak rata, becek. 2) Faktor dari dalam, yaitu: (a) Faktor anatomi. Panjang tungkai yang tidak sama, arcus kaki rata, kaki jinjit, sehingga pada waktu lari akan mengganggu gerakan. (b) Latihan gerakan yang keliru misalnya: pada saat shooting ataupun passing. (c) Adanya kelemahan otot. d) Tingkat kebugaran rendah 3) Penggunaan yang berlebihan/overuse. Gerakan atau latihan yang berlebihan dan berulang-ulang dalam waktu relatif lama/mikro trauma dapat menyebabkan cedera (Roald et al, 2020)

Resiko cedera lebih tinggi tingkat kejadiannya pada olahraga prestasi dibanding olahraga yang hanya untuk kebugaran. Olahraga prestasi dituntut untuk memenuhi target tertentu sehingga setiap pelaku olahraga atau atlet yang masuk dalam olahraga prestasi akan berusaha semakin keras apapun risikonya dalam memenuhi target tersebut. Selain itu, Olahraga permainan bola besar merupakan salah satu cabang olahraga dengan tingkat kejadian cedera paling tinggi. Dilihat dari segi klasifikasi cederanya juga semua bisa terjadi pada setiap klasifikasi cabang olahraga ini. Jenis cabang olahraga ini membutuhkan komponen kebugaran jasmani yang baik pula, karena dalam permainannya kadang kala temponya berubah dari lambat ke cepat dan sebaliknya. Maka dari itu program rehabilitasi olahraga sangat dibutuhkan untuk atlet yang mengalami cedera agar supaya atlet kembali bugar dan kembali ke performa terbaiknya dalam waktu yang sangat singkat.

Hasil penelitian yang dilakukan pada Atlet Puslatda KONI Jawa Timur di Surabaya bahwa tingkat keberhasilan program rehabilitasi olahraga dalam kategori berhasil dan sangat berpengaruh besar terhadap kesembuhan dan pemulihan dengan waktu yang sangat singkat (Rohman, 2019). 
Banyak atlet dari Kota Malang menjadi pilihan untuk mewakili event olahraga. Mulai dari Pekan Olahraga Provinsi hingga Asian Games. Sebagai Kota terbesar kedua di Jawa Timur dan juga termasuk kota yang bisa dibilang maju akan olahraga permainannya seperti Sepakbola, Futsal, Bolavoli maupun Bolabasket, karena itulah KONI Malang sangat berupaya dalam membina atlet sampai ke performa terbaiknya. Munculnya atlet berprestasi di Kota Malang yang sedemikian rupa maka akan menambah motivasi dari pihak KONI Kota Malang untuk menjadi wadah bagi atlet-atlet tersebut. Sehingga KONI Kota Malang akan berupaya mengadakan pembinaan usia dini melalui scouting atau pemanduan bakat serta pemantauan program latihan dari masing-masing cabang olahraga. Dari langkah-langkah yang dilakukan oleh KONI Kota Malang tentu diharapkan akan mencetak banyak atlet yang unggul baik dari segi fisik, mental, dan moral. Dan mampu bersaing ditingkat nasional bahkan internasional dengan dibekali keterampilan (Hendra, 2019). Namun tidak hanya keterampilan yang menjadi bekal utama dalam event-event besar tersebut KONI Kota Malang harus juga memperhatikan penanganan dan penyembuhan terhadap atlet yang mengalami cedera sebab jadwal yang padat antara latihan, istirahat, dan saat bertanding akan mempengaruhi kondisi atlet tersebut.

Berdasarkan permasalahan yang diatas tujuan dilakukan penelitian ini yaitu untuk mengetahui tingkat keberhasilan program pasca cedera olahraga pada Atlet Bola Besar Kota Malang.

\section{Metode}

Metode penelitian ini menggunakan kuantitatif deskriptif dengan menggunakan pendekatan survei. Jumlah sampel dalam penelitian ini yaitu 21 atlet putra dengan cabang olahraga Sepakbola, Bolabasket, Bolavoli dan Futsal KONI Kota Malang dengan menggunakan teknik Proportionate Stratified Random Sampling dan proporsi yang digunakan setiap cabang olahraga adalah $25 \%$.

Teknik pengumpulan data dalam penelitian ini adalah menggunakan kuesioner dan disajikan dalam bentuk google form. Skala dalam kuesioner penelitian ini menggunakan skala likert dengan skala 5. Analisis data menggunakan aplikasi statistik IBM SPSS versi 26.0, dan pengkategorian pengetahuan didasarkan pada norma pengetahuan.

Atlet olahraga permainan bola besar dalam penelitian ini adalah atlet putra yang mengikuti event Porprov tahun 2019 dengan rentangan usia 19-22 tahun. Tingkat keberhasilan yang dimaksud adalah keberhasilan program latihan mengenai motivasi dan fungsionalnya saat melakukan program pasca cedera atau program rehabilitasi olahraga, serta keberhasilan program latihan mengenai biomekanika gerak setiap fase latihan pasca cedera atau program rehabilitasi olahraga. Sedangkan olahraga permainan bola besar meliputi cabng olahraga Sepakbola, Bolabasket, Bolavoli, dan Futsal.

Data dianalisis menggunakan norma tingkat keberhasilan sebagai berikut:

Tabel 1. Norma Tingkat Keberhasilan

\begin{tabular}{clc}
\hline No & \multicolumn{1}{c}{ Norma } & Kategori \\
\hline 1 & $\mathrm{M}+1,5 \mathrm{SD}<\mathrm{X}$ & Sangat Berhasil \\
2 & $\mathrm{M}+0,5 \mathrm{SD}<\mathrm{X} \leq \mathrm{M}+1,5 \mathrm{SD}$ & Berhasil \\
3 & $\mathrm{M}-0,5 \mathrm{SD}<\mathrm{X} \leq \mathrm{M}+0,5 \mathrm{SD}$ & Berimbang \\
4 & $\mathrm{M}-1,5 \mathrm{SD}<\mathrm{X} \leq \mathrm{M}-0,5 \mathrm{SD}$ & Tidak Berhasil \\
5 & $\mathrm{X} \leq \mathrm{M}-1,5 \mathrm{SD}$ & Sangat Tidak Berhasil \\
\hline
\end{tabular}


Sumber : (Azwar, 2013)

Keterangan :

M : Mean

SD : :Standar Deviasi

$\mathrm{X} \quad$ : Skor

Dan perhitungan tingkat capaian responden menggunakan norma sebagai berikut.

Tabel 2. Norma Tingkat Capaian Responden

\begin{tabular}{rlc}
\hline No & Kriteria & TCR (\%) \\
\hline 1 & Sangat Baik & $90-100$ \\
2 & Baik & $80-89$ \\
3 & Cukup Baik & $70-79$ \\
4 & Kurang Baik & $55-69$ \\
5 & Tidak Baik & $1-54$ \\
\hline
\end{tabular}

Sumber : (Riduwan \& Sunarto, 2017)

Keterangan :

TCR : Tingkat Capaian Responden

\section{Hasil dan Pembahasan}

Hasil yang didapat menjelaskan bahwa tingkat keberhasilan program rehabilitasi atlet permainan bola besar Kota Malang memiliki rata-rata atau mean sebesar 95,5 dan nilai standar deviasi sebesar 12,278. Berdasarkan nilai mean dan standar deviasi yang diperoleh, kemudian dianalisis berdasarkan norma perkategorian maka tingkat keberhasilan program rehabilitasi olahraga pada atlet permainan bola besar Kota Malang termasuk dalam kategori berimbang.

Tabel 3. Nilai Statistik

\begin{tabular}{cccc}
\hline Mean & Variance & Std. Deviation & N of Items \\
\hline 95,05 & 150,748 & 12,278 & 25 \\
\hline
\end{tabular}

Dari hasil tabel 5 sebagian besar tingkat keberhasilan dalam kategori berimbang yaitu berjumlah 10 atau 47,6\%. Kemudian nilai paling kecil yaitu pada kategori sangat tidak berhasil yaitu 1 atau 4,8\% dari total responden, sedangkan dalam kategori tidak berhasil berjumlah 6 atau 28,6\%, kategori berhasil berjumlah 2 atau 9,5\%, dan kategori sangat berhasil berjumlah 2 atau $9,5 \%$.

Dan hasil tingkat capaian responden yang disajikan dalam tabel 4 dapat dianalisis bahwa nilai maksimal capaian responden diperoleh dalam faktor Motivasi dan fungsi sedangkan nilai minimal diperoleh dalam faktor evaluasi biomekanika dan evaluasi setiap fase latihan.

Tingkat capaian responden semua cabang olahraga diperoleh bahwa seluruh cabang olahraga dalam kategori berimbang. Dengan nilai terendah didapat cabang olahraga bolavoli dengan tingkat capaian $69,4 \%$ dan tingkat capaian tertinggi diperoleh cabang olahraga sepakbola dengan tingkat capaian 79,8\%. 
Tabel 4. Tingkat Capaian Responden

\begin{tabular}{clcc}
\hline No & Faktor & TCR (\%) & Kategori \\
\hline $\mathbf{1}$ & Motivasi \& Fungsi & 75 & Berimbang \\
$\mathbf{2}$ & Evaluasi Biomekanika \& Evaluasi Setiap Fase Latihan & 82 & Berhasil \\
TCR (\%) Keseluruhan & 79 & Berimbang \\
\hline Keterangan : & & \\
TCR : Tingkat Capaian Responden & &
\end{tabular}

Tabel 5. Kategorisasi Tingkat Pengetahuan

\begin{tabular}{llll}
\hline \multicolumn{1}{c}{ Norma } & \multicolumn{1}{c}{ Kategori } & \multicolumn{1}{c}{ Jumlah } & Persentase \\
\hline $\mathbf{X} \leq \mathbf{M}-\mathbf{1 , 5}$ SD & Sangat Tidak Berhasil & 1 & 4,8 \\
$\mathbf{M}-\mathbf{1 , 5}$ SD $<$ X $\leq \mathbf{M}-\mathbf{0 , 5}$ SD & Tidak Berhasil & 6 & 28,6 \\
$\mathbf{M}-\mathbf{0 , 5}$ SD $<$ X $\leq \mathbf{M}+\mathbf{0 , 5}$ SD & Berimbang & 10 & 47,6 \\
$\mathbf{M}+\mathbf{0 , 5}$ SD $<$ X $\leq \mathbf{M}+\mathbf{1 , 5}$ SD & Berhasil & 2 & 9,5 \\
$\mathbf{M}+\mathbf{1 , 5}$ SD $<$ X & Sangat Berhasil & 2 & 9,5 \\
Total & & 21 & 100,0 \\
\hline
\end{tabular}

Keterangan :

M : Mean

SD : Standar Deviasi

X : Skor

\subsection{Motivasi \& Fungsi}

Pengetahuan cedera olahraga harus dikuasai oleh setiap pelaku olahraga. Pengetahuan mengenai faktor istilah-istilah, pencegahan, penanganan, dan rehabilitasi cedera olahraga merupakan hal yang mendasari dalam pengetahuan cedera olahraga. Karena hal ini akan menjadi penentuan sikap dari cedera olahraga.

Masih banyak yang menganggap ankle dan hamstring sebagai salah satu jenis cedera, padahal masing-masing dari kedua tersebut adalah bagian dari anggota tubuh. Hal ini harus diperhatikan mengingat setiap jenis cedera pasti penangannya juga akan berbeda. Definisi cedera olahraga adalah fenomena fluida, Karena itu cedera olahraga tidak boleh terjadi dipandang sebagai kondisi kesehatan itu sendiri, tetapi seharusnya dipandang sebagai interaksi antara kerusakan fisik dan faktor kontekstual (Bolling, Delfino Barboza, van Mechelen, \& Pasman, 2019).

Atlet juga belum paham tentang jangka waktu dalam kejadian cedera olahraga, masih ragu-ragu dalam menjawab cedera akut merupakan cedera yang terjadi seketika atau saat itu juga. Pengetahuan akan jangka waktu dalam cedera ini sangat penting dalam memberikan keputusan seberapa parah dan berapa lama cedera yang dialami dapat pulih kembali.

Dengan demikian kemungkinan pengambilan sikap terhadap cedera olahraga pada atlet akan berpengaruh pada kondisi kesehatan fisik. Ketika terjadi cedera olahraga atlet akan berusaha menekan rasa sakit yang diterima akibat cedera yang berisiko menjadi parah dan lebih mementingkan bertanding. Atlet tidak memikirkan risiko yang diterima tentang sifat cedera dalam jangka panjang. Perilaku tersebut didasarkan pada sifat kompetitif atlet yang meningkat seiring dengan bertambahnya usia (Whatman, Walters, \& Schluter, 2018). Kondisi tersebut bisa memperburuk tingkatan cedera jika dipaksakan bermain, selain itu dapat menghasilkan beban biaya yang lebih mahal dalam rehabilitasi olahraga. 
Pencegahan cedera olahraga merupakan faktor dari segi usaha untuk mengurangi atau menghindari segala sesuatu yang menyebabkan terjadinya cedera yang akan terjadi pada atlet maupun diri sendiri. Namun dalam penggunaan alat proteksi atau pelindung masih dianggap remeh bagi atlet, Perlengkapan dan peralatan yang nyaman akan sangat membantu mencegah terjadinya cedera olahraga, membantu gerak dalam berolahraga lebih ergonomis. Selain itu juga menghindarkan dari inflamasi ringan akibat dari perlengkapan dan peralatan yang dipakai. Peluang terbaik dalam mengurangi cedera olahraga dapat melalui peraturan dan peralatan pelindung yang ditingkatkan (Fraser, Grooms, Guskiewicz, \& Kerr, 2017).

Program latihan juga penting selain meningkatkan performa dan mencegah terjadinya cedera. Tanpa adanya program latihan yang jelas risiko terjadinya cedera olahraga dalam menjalankan latihan bisa terjadi lebih parah. Strategi lain seperti beban pelatihan, pemantauan kesejahteraan, tidur atau nutrisi bisa dijadikan edukasi bagi para atlet maupun staf kepelatihan sebagai strategi mereduksi cedera olahraga (Crossley et al., 2020).

Penanganan cedera olahraga adalah faktor yang membutuhkan wawasan yang sangat baik, sebab jika penanganan pertama cedera salah maka cedera olahraga yang dialami akan sangat parah bahkan berisiko cacat permanen. pemberian tepat awal dan penanganan luka harus segera diberikan sesegera mungkin untuk dihindari komplikasi yang timbul akibat cedera (Gita, Dian, \& Nawang, 2020).

Hasil penelitian terdapat bahwa banyak atlet beranggapan jika memasukkan tulang yang keluar pada saat terjadi patah tulang terbuka adalah hal yang benar. Sedangkan hal itu sangat tidak diperbolehkan dalam medis sebab tulang yang keluar sudah terinfeksi oleh kuman atau virus, penanganan pertama yang benar adalah sebaiknya hanya dibidai. Irigasi dan debridement luka, reduksi dan stabilisasi fraktur, profilaksis infeksi oleh antibiotik dan cakupan jaringan lunak awal adalah langkah-langkah penting pengobatan (Ömeroğlu, 2018).

Pemahaman atlet dalam menangani cedera sprain masih tergolong rendah. Para atlet lebih sering menggunakan krim pemanas atau balsem saat menangani cedera sprain. RICE merupakan metode penanganan pertama yang bertujuan untuk meredakan pembengkakan dan mengatur aliran darah pada daerah cedera. Sebagai modalitas terapi gabungan, penggunaan RICE plus fisioterapi multimodal dibandingkan dengan RICE saja tidak ada manfaat tambahan. Kedua metode tersebut memberikan pengurangan rasa sakit, meningkatkan fungsi dan mengurangi pembengkakan pada sprain (Vuurberg et al., 2018).

\subsection{Evaluasi Biomekanika \& Evaluasi Setiap Fase Latihan}

Hasil lain menandakan bahwa atlet olahraga permainan bola besar Kota Malang belum sepenuhnya mengerti tentang rehabilitasi olahraga. mereka masih belum mengerti tentang prosedur yang digunakan dalam menjalani latihan dalam rehabilitasi olahraga. Pemahaman fase-fase latihan perlu dijadikan acuan untuk menjalani latihan dalam rehabilitasi olahraga. Banyak atlet menjawab bahwa fase-fase latihan dapat dilakukan secara selang-seling atau tidak runtut, tetapi fase latihan dalam rehabilitasi olahraga harus runtut dan dijalani setiap fase berdasarkan tujuan latihannya. Temuan dalam penelitian ini adalah banyak yang menganggap atlet bisa kembali latihan ke lapangan atau dalam tim pasca operasi oleh dokter. Anggapan ini sepenuhnya salah sebab setelah operasi atlet harus memenuhi fase-fase latihan pemulihan. Fase awal dalam pemulihan yaitu fase untuk mereduksi inflamasi atau gejala-gejala cedera. Fase sub-akut yaitu pengembalian Range of Motion (ROM) dan penguatan otot. Fase 
Transisi yaitu fase peningkatan performa sesuai cabang olahraga dan level masing-masing atlet. Perkembangannya harus secara kontinyu dengan kriteria fungsional berdasarkan waktu untuk dapat menentukan ke tahap berikutnya (Dhillon, 2017).

Cedera adalah fenomena yang umum terjadi pada olahraga baik olahraga yang kontak fisik maupun non kontak fisik. Dan jika tidak ditangani secara tepat dan cepat bisa berakibat cacat pada atlet. Rehabilitasi adalah proses pengembalian fungsi atlet sepenuhnya yang mengalami cedera. Ini terdiri dari berbagai modalitas terapi seperti latihan dan praktik kesehatan yang dilakukan segera setelah cedera dan berlanjut pada pemulihan sepenuhnya (Rao, 2017).

Penelitian terdahulu telah menunjukkan bahwa latihan resisten paling ampuh untuk mengembangkan kekuatan sendi dan otot yang lemah dan dengan demikian memainkan peran penting dalam rehabilitasi. Penggunaan beban dalam latihan umumnya digunakan melalui beberapa gerakan dari ekstensi ke fleksi lengan dan kaki yang terkena. Latihan ini dapat menggunakan bantuan beban, tali, atau dapat menggunakan beban tubuh.

Sebelum atlet memasuki fase return to sport, perlu adanya tes faktor psikososial meliputi trauma, dan ketidaknyamanan saat melakukan pergerakan. Hal ini sangat mendasari keputusan untuk atlet bisa berlatih kembali ke lapangan dan masuk dalam daftar tim untuk bertanding. Pengujian juga harus memasukkan gerakan khusus yang berhubungan dengan cabang olahraga atlet dengan intensitas dan kecepatan mendekati maksimum (Erickson \& Sherry, 2017).

Program rehabilitasi harus memulihkan gerakan dan proprioception, menjaga kebugaran kardiovaskular, dan meningkatkan kekuatan otot, daya tahan, dan kekuatan, terutama melalui closed-chain exercises. Pengukuran hasil rehabilitasi berfokus pada tingkat kerusakan individu sebelum dan sesudah rehabilitasi.

Dengan demikian keputusan untuk atlet dapat melanjutkan latihan dalam tim bisa diperoleh dari hasil pengujian tersebut. Untuk hasil yang lebih maksimal dan mencegah cedera tidak kambuh lagi saat memulai kompetisi.

\section{Simpulan}

Dari hasil analisis tingkat keberhasilan program latihan pasca cedera, diperoleh hasil data yang sudah diolah bahwa analisis tingkat keberhasilan program latihan pasca cedera pada atlet olahraga permainan Kota Malang yaitu berimbang, sedangkan sisanya masuk dalam kategori sangat tidak berhasil, tidak berhasil, sangat berhasil, dan berhasil. Perlu adanya peningkatan dari motivasi atlet saat mengalami cedera dan perlu adanya peningkatan dari pemahaman atlet bahwa program latihan pasca cedera tidak seperti yang dibayangkan sebelumnya oleh atlet.

\section{Ucapan Terima Kasih}

Terimakasih kepada teman-teman yang bekerja sama terhadap penelitian ini dan kepada pihak KONI Kota Malang yang sudah memberikan izin serta dukungan terhadap peelitian ini. 


\section{Daftar Rujukan}

Azwar. (2013). Metode Penelitian. Yogyakarta: Pustaka Pelajar. Azwar.

Bolling, C., Delfino Barboza, S., van Mechelen, W., \& Pasman, H. R. (2019). How elite athletes, coaches, and physiotherapists perceive a sports injury. Translational Sports Medicine, 2(1), 17-23. https://doi.org/10.1002/tsm2.53

Crossley, K. M., Patterson, B. E., Culvenor, A. G., Bruder, A. M., Mosler, A. B., \& Mentiplay, B. F. (2020). Making football safer for women: A systematic review and meta-Analysis of injury prevention programmes in 11773 female football (soccer) players. British Journal of Sports Medicine, 54(18), 1089-1098. https://doi.org/10.1136/bjsports-2019-101587

Dhillon, H. (2017). Current Concepts in Sports Injury Rehabilitation. Indian Journal of Orthopaedics, 51(5), 529536. https://doi.org/10.4103/ortho.IJOrtho

Dwiariani, D. A. (2012). Peran pelatihan mental dalam proses penurunan kecemasan cedera berulang pada atlet putri bola basket. Depok: PPS Universitas Indonesia.

Erickson, L. N., \& Sherry, M. A. (2017). Rehabilitation and return to sport after hamstring strain injury. Journal of Sport and Health Science, 6(3), 262-270. https://doi.org/10.1016/j.jshs.2017.04.001

Fraser, M. A., Grooms, D. R., Guskiewicz, K. M., \& Kerr, Z. Y. (2017). Ball-contact injuries in 11 national collegiate athletic association sports: The injury surveillance program, 2009-2010 through 2014-2015. Journal of Athletic Training, 52(7), 698-707. https://doi.org/10.4085/1062-6050-52.3.10

Gita, E. G. A., Dian, T. A., \& Nawang, G. (2020). Knowledge Levels Of Rest, Ice, Compression, Elevation Method With The Implementation Of Injury Handling In Sport Student Activity Units. Journal Widya Medika Junior, 2(1), 38-46. https://doi.org/10.33508/jwmj.v2i1.2334

Hendra, S. (2019). Prestasi, ini nama atlet Kota Malang yang mewakili indonesia di Sea Games 2019. JatimTimes.com.

International Olympic Committee Injury and Illness Epidemiology Consensus Group, Bahr, R., Clarsen, B., Derman, W., Dvorak, J., Emery, C. A., ... \& Chamari, K. (2020). International Olympic Committee consensus statement: methods for recording and reporting of epidemiological data on injury and illness in sports 2020 (including the STROBE extension for sports injury and illness surveillance (STROBESIIS)). Orthopaedic journal of sports medicine, 8(2), 2325967120902908.

Ömeroğlu, H. (2018). Basic principles of fracture treatment in children. Eklem Hastaliklari ve Cerrahisi, 29(1), 52-57. https://doi.org/10.5606/ehc.2018.58165

Rao, N. R. C. (2017). Effect of rehabilitation programme on injured inter- collegiate men volley-ball players. $4(5), 230-232$.

Riduwan, \& Sunarto. (2017). Pengantar Statistika untuk Penelitian: Pendidikan, Sosial, Komunikasi, Ekonomi dan Bisnis. In Alfabeta, Bandung.

Rohman, A. (2019). Analisis Tingkat Keberhasilan Rehabilitasi Atlet Puslatda Yang Mengalami Cedera Soetanto Hartono Abstrak.

Vuurberg, G., Hoorntje, A., Wink, L. M., Van Der Doelen, B. F. W., Van Den Bekerom, M. P., Dekker, R., ... Kerkhoffs, G. M. M. J. (2018). Diagnosis, treatment and prevention of ankle sprains: Update of an evidence-based clinical guideline. British Journal of Sports Medicine, 52(15), 956. https://doi.org/10.1136/bjsports2017-098106

Whatman, C., Walters, S., \& Schluter, P. (2018). Coach and player attitudes to injury in youth sport. Physical Therapy in Sport, 32, 1-6. https://doi.org/10.1016/j.ptsp.2018.01.011 